ACRL

\section{Guidelines}

\title{
Guidelines regarding thefts in libraries: Draft version
}

\section{Attend the bearings at the ALA Annual Conference in Miami}

\section{Section I. What to Do Before a Library Theft Occurs}

\section{Library security officer (ISO)}

Appoint a senior library staff member as Library Security Officer (LSO) who has delegated authority from the library and the institution to act on their behalf working with the institution's legal counsel and security force.

\section{Security planning group}

Form a group made up of the LSO and other appropriate personnel to develop a specific plan of action to follow when a theft is discovered. This may be a part of the institution's disaster plan or a separate plan.

\section{Publicity}

Establish liaison with the institution's public relations office so that timely and accurate announcements can be made to the press when a theft is discovered.

\section{Law enforcement}

A. Establish contact and foster good working relations with law enforcement agencies-institutional, local, state, and/or federal-to determine who will be called and under what circumstances. The library should maintain a list of contacts in each level of law enforcement and discuss the plan of action with each. (See Appendix I for "Networking Resources Directory for Protection and Recovery.") The value of materials or other circumstances will dictate which law enforcement agency will handle the case: for example, the FBI may be involved if the total dollar amount of the theft exceeds $\$ 5,000.00$, and the U.S. Customs or Interpol may be involved if stolen items are suspected of being smuggled into or out of the country.

B. Work with the library's institutional administration to insure support for the prosecution of thieves. This support may range from an active willingness to participate in the collection of evidence to be turned over to the district attorney or U.S. attorney for further consideration, or it may involve direct participation in the prosecution by the institution.

C. Work with appropriate institutional, local, and state groups to lobby for strengthening of state laws regarding library thefts and for diligent prosecution of such crimes. (See Appendix II for "Draft of Model Legislation: Theft and Mutilation of Library Materials.")

\section{Other outside contacts}

A. Establish liaison with local rare book, manuscript, and second-hand dealers to inform them of the library's collecting areas. Thieves sometimes try to sell stolen property quickly, and dealers with knowledge of the library's collections can recognize, or at least be suspicious of, materials they know the library collects which are offered to them.

$B$. Report the name of the LSO to the RBMS Security Committee and note changes. The RBMS Security Committee will compile a list of the LSOs annually. The list will be available from the ACRL office and will be forwarded to the Antiquarian Booksellers Association of America (ABAA).

C. Establish liaisons with appropriate Internet listservs and national stolen and missing book databases (see Appendix I for "Networking Resources Directory for Protection and Recovery") so that thefts can be reported immediately upon discovery.

\section{Preventive measures in the library}

A. Implement the RBMS "Guidelines for the 
Security of Rare Book, Manuscript, and Other Special Collections" (1990) available from the ACRL office and published in CERL News 51 (March 1990): 240-44.

B. Coordinate work in the library to assure that unique ownership marks appear on the institution's holdings, providing proof that materials, if stolen, belong to the library. The RBMS Security Committee urges the use of its marking guidelines for rare materials. (See "Guidelines for the Security of Rare Book, Manuscript, and Other Special Collections," Appendix I.) The committee also recommends recording distinctive characteristics of individual copies in cataloging notes as another means of identifying appropriate items.

C. When providing complete catalog records at point of receipt is not possible, maintaining a brief record of ownership is recommended. It should contain brief author/title description and identifying characteristics. These records of purchase or gift and ownership are especially important when materials are going to be added to a cataloging backlog.

D. Eliminate cataloging backlogs. While this may seem to be a daunting task in many librar- ies, it is an essential step in the establishment of a secure library collection. Use the catalog record to describe physical characteristics that distinguish the library's copy (i.e., binding, marks of previous ownership, and completeness). Create machine-readable records for local public access. Report the library's holdings to the national-level bibliographic databases. Participate in broad-based bibliographic projects providing data and information about the library's copies that serve to help distinguish between editions, issues, and states.

E. Conduct regular inventories of both cataloged and uncataloged collections. This task is most effectively performed by staff working in teams, and conducted on a random basis. Proceeding through the collection in a predictable method is not wise as it may allow for the replacement of materials temporarily removed or stolen. An inventory of shelf list cards to be taken simultaneously is also recommended, if this is not already a part of the procedure being followed. Again, while the task seems overwhelming for libraries large and small, the committee recommends that libraries make a beginning.

\section{About the guidelines}

The "Guidelines Regarding Thefts in Libraries" have been developed by the ACRL Rare Books and Manuscripts Section's (RBMS) Security Committee over the past ten years. The committee began in 1978 with an ad hoc charge to develop guidelines for the marking of rare materials so that they could be properly identified when recovered. First published in 1979, these were later made an appendix to the broader "Guidelines for the Security of Rare Book, Manuscript, and Other Special Collections," published by ACRL in 1982, and revised in 1990.

From 1983 to 1986 successive drafts of "Guidelines Regarding Thefts in Libraries" were reviewed by the RBMS Security Committee. The final draft was approved by the ACRL Board of Directors and the ALA Standards Committee and published in C\&RL News in March 1988. These guidelines included sections entitled "What to do before a theft occurs"; "What to do after a theft occurs," or steps to follow when a theft has been discovered; and "Model legislation: Theft and mutilation of library materials," which the committee hoped libraries and ACRL chapters would take to their state legislatures to strengthen the laws for the prosecution and punishment of $\mathrm{l}_{i}$ brary thieves. What follows is a revision begun in 1993 by the current RBMS Security Committee. All sections have been retained. The lirst two sections have been retained with some minor revision of style and augmentation of content. The third section, "Model legislation," has become Appendix II.
The RBMS Security Committee wishes to emphasize two important points about "Guidelines Regarding Thefts in Libraries." First, these guidelines do not stand alone. They are interrelated to other RBMS published guidelines and should be considered in conjunction with the other guidelines. Second, these guidelines concern all library thefts, not just those which may occur in rare book, manuscript, and other special collections departments within a library system. Some informal surveys over the past few years have shown that these latter departments have stronger physical and procedural security systems in place than do their parent libraries for the general collections. Yet, a library is only as secure as its perimeter. Publicized thefts in the last decade such as the Shinn and Blumberg cases show that thieves infiltrated both established systems in special collections departments and open stacks areas where rare materials acquired years before remained unidentified and unprotected.

It is paramount that ACRL and ALA encourage the implementation of these guidelines, including the appointment of a Library Security Officer (LSO) at individual libraries. The committee stands ready to work with these LSOs to improve communication about theffs and to assist in the education of all librarians about the epidemic proportions of library thefts and the means to cope with them.

Committee members are: Susan M. Allen, chair; George Arnold; Virginia Bartow; Lois Fischer Black; Daren Callahan; Heather Lloyd; Eric Macdonald; Everett C. Wilkie; and Melissa Conway, intern. 
F. Follow the hiring and other management practices recommended in "Standards for Ethical Conduct for Rare Book, Manuscript, and Special Collections Librarians, with Guidelines for Institutional Practice in Support of the Standards," 2nd edition, 1992, available from the ACRL office and published in CERL News 54 (April 1993): 207-15.

G. Review materials in the library's general collections and open stacks for consideration of transfer to special collections or to a caged, limited access area of the library. The ACRL/ RBMS transfer guidelines, "Selection of General Collection Materials for Transfer to Special Collections," 2nd edition, available from the ACRL office and published in CERL News 54 (December 1993): 644-47, will help the library identify candidates for transfer. Some libraries have identified rare materials in the open stacks in the course of projects, such as reporting to the English Short Title Catalogue or working through a collection development policy using the Research Libraries Group Conspectus. While the task seems overwhelming for libraries large and small, the RBMS Security Committee recommends that libraries make a beginning.

A recent theft may give an indication of an area which may be the target of future theft or mutilation. If it is appropriate, transfer materials intellectually or physically related to those already stolen or mutilated. Categories of such materials may but will not necessarily include periodicals, related imprints, or related subject matter.

\section{Section II. Checklist of What to Do After a Theft Occurs from a Library} I. Notification

- Notify the LSO and appropriate library administrators upon suspicion that a theft has occurred.

\section{Discovery of theft and collection of evi- dence}

- Evidence of intrusion connected with missing library materials.

- Indication that patron, staff member, or other has stolen books or manuscripts.

- Apprehension of person(s) in act of theft.

- Discovery of systematic pattern of loss.

- Recovery of materials stolen from library.

- Other evidence.

\section{Evaluation}

The LSO must evaluate evidence with adminis- tration, law enforcement personnel, library security group, and legal counsel as appropriate, and determine a plan of action.

\section{Actions}

- Take inventory and compile a list of missing items.

- Notify appropriate stolen and missing book databases and other appropriate networks. (See Appendix I for "Networking Resources Directory for Protection and Recovery.")

- Notify local booksellers and appropriate specialist dealers.

- Request action from law enforcement agencies.

- Request action from legal authorities.

- Transfer vulnerable items to a more secure location, if appropriate.

\section{Publicity}

- LSO, administration, law enforcement, and public relations officer plan appropriate publicity strategy.

- LSO or public relations officer prepares news releases to alert staff and community to problems and action.

- LSO or public relations officer handles inquiries from news media.

\section{LSO's coordination of staff efforts should include}

- Compilation of inventories.

- Arrangement for appraisals of loss or recovery.

- Preparation of communications to staff about progress on case.

- Maintenance of internal records of actions followed during the progress of case.

\section{Share your library's news}

CERL News wants to hear about your library's activities. Information in the News from the Field, Grants \& Acquisitions, and People in the News columns is gathered from press releases and notices we receive. If you don't share your ideas and activities with us we can't share them with CERL News readers. Be sure to put CERL News on your mailing list today. Send notices to the Editor, CERL News, 50 E. Huron St., Chicago, IL 60611; or e-mail: U38398@uicvm.uic.edu. 


\section{APPENDIX I}

\section{Networking Resources Directory for Protection and Recovery}

The AB Bookman's Weekly

Jacob L. Chernofsky, Editor \& Publisher P.O. Box $A B$

Clifton, NJ 07015

phone: (201) 772-0020

fax: (201) 772-9281

(Publishes a missing books column at reduced rates)

ABAA National Office

Liane Wood-Thomas

Executive Director

50 Rockefeller Plaza

New York, NY 10020

phone: (212) 757-9395

(Circulates lists of missing materials to membership)

\section{ABAA Security Committee}

Ron Lieberman, Chair

R.R. 1 Box 42

Glen Rock, PA 17327

phone: (717) 235-2134

fax: (717) 235-8042

ACRL/RBMS Security Committee

Susan M. Allen, Chair

Director of Libraries \& Media Services

Kalamazoo College Library

1200 Academy Street

Kalamazoo, MI 49006-3285

phone: (616) 337-7149

fax: (616) $337-7143$

Internet: sallen@kzoo.edu

(Compiles incidents of theft list; LSO list)

Archives and Archivists

To subscribe send the message:

SUB ARCHIVES < your first name your last name>

to:

archives@miamiu.acs.muohio.edu

(Listserv for archivists)
BAM-BAM

Katharine and Daniel Leab

P.O. Box 1236

Washington, CT 06793

phone: (212) 737-2715

(Compiles missing materials list)

EXIIBRIS

To subscribe send the message:

Subscribe exlibris your_full_name

to:

listserv@rutvm1.bitnet

or:

listserv@rutvm1.rutgers.edu

(Listserv for rare books and manuscripts librarians)

IFAR

International Foundation for Art Research

Constance Lowenthal

46 E. 70th St.

New York, NY 10021

phone: (212) 879-1780

(Newsletter includes a column listing missing materials)

Interpol/USNCB

Angela Meadows

U.S. Department of Justice

10th \& Pennsylvania Ave. NW

Washington, DC 20530

phone: (202) 272-8383

fax: (202) 272-5941

(Circulates information internationally)

National Stolen Art File

Interstate Theft Unit

FBI Headquarters

Washington, DC

phone: (202) FBI-3000

(Database of stolen artifacts; will add books soon. Cannot be queried directly; work through local law enforcement) 


\section{APPENDIX II}

\section{Draft of Model Legislation: Theft and Mutilation of Library Materials}

\section{Declaration of purpose}

Because of the rising incidence of library theft and mutilation of library materials, libraries are suffering serious losses of books and other library property. In order to assure that research materials are available for public use, it is the policy of this state to provide libraries and their employees and agents with legal protection to ensure security for their collection. It is the policy of this state to affirm that local, state, and fecleral prosecution of crimes affecting books or other library property is executed with the same degree of diligence as is exercised in prosecution of crimes affecting all other forms of property. Federal statute pertaining to stolen property is designed not only to implement federal-state cooperation in apprehending and punishing criminals who utilize, or cause to be utilized, channels of interstate commerce for transportation of property (in value of $\$ 5,000$ or more) of which the owner has been wrongfully deprived, but also to deter original theft.

\section{Definition of terms}

"Library" means any public library; any library of an educational, benevolent, hereditary, historical, or eleemosynary institution, organization, or society; any museum; any repository of public or institutional records. "Book or other library property" means any book, plate, picture, photograph, print, painting, drawing, map, newspaper, magazine, pamphlet, broadside, manuscript, document, letter, public record, microform, sound recording, audiovisual material in any format, magnetic or other tape, catalog card or catalog record, electronic data processing record, artifact, or other documentary, written, or printed materials, or equipment, regardless of physical form or characteristics, belonging to, on loan to, or otherwise in the custody of a library.

\section{Proposed wording}

Section I.a. Any person who willfully, maliciously, or wantonly writes upon, injures, defaces, tears, cuts, mutilates, or destroys any book or other library property belonging to, on loan to, or otherwise in the custody of a library shall be guilty of a crime.

Section I.b. The willful concealment of a book or other library property upon the person or among the belongings of the person or concealed upon the person or among the belongings of another while still on the premises of a library shall be prima facie evidence of intent to commit larceny thereof.

Section I.c. The willful removal of a book or other library property in contravention of library regulations shall be prima facie evidence of intent to commit larceny thereof.

Section I.d. The willful alteration or destruction of library ownership records, electronic or card catalog records retained apart from or applied directly to a book or other library property shall be prima facie evidence of intent to commit larceny of a book or other library property.

Section II.a. An adult agent or employee of a library who has reasonable grounds to believe that a person committed, was committing, or was attempting to commit the acts described in Section I may stop such person. Immediately upon stopping such person, the library employee shall identify himself or herself and state the reason for stopping the person. If after initial confrontation with the person under suspicion, the adult agent or library employee has reasonable grounds to believe that at the time stopped, the person committed, was committing, or was attempting to commit the crimes set forth in Section I, said employee or agent may detain such person for a time sufficient to summon a peace officer to the library. In no case shall the detention be for a period of more than one-half hour. Said detention must be accomplished in a reasonable manner without unreasonable restraints or excessive force and may take place only on the premises of the library where the alleged crime occurred. Library premises includes the interior of a building, structure, or other enclosure in which a library facility is located; the exterior appurtenances to such building, structure, or other enclosure; and the land on which such building, structure, or other enclosure is located. Any person so stopped by an employee or agent of a library shall promptly identify himself or herself by name and address. Once placed under detention, such person shall not be required to provide any other information nor shall any written and/or signed statement be elicited from such person until a peace officer has taken such person into custody. The 
said employee or agent may, however, examine said property which the employee or agent has reasonable grounds to believe was unlawfully taken as set forth in Section I.b and/or I.C or injured or destroyed as set forth in Section I. a and/or I.d. Should the person detained refuse to surrender the item for examination, a limited and reasonable search may be conducted. Only packages, shopping bags, handbags, or other property in the immediate possession of the person detained, but not including any clothing worn by the person, may be searched

Section II. b. For the purposes of Section II.a, "reasonable grounds" shall include, but not be limited to, knowledge that a person has concealed or injured a book or other library property while on the premises of the library.

Section II.C. In detaining a person who the employee or agent of the library has reasonable grounds to believe committed, was committing, or was attempting to commit any of the crimes set forth in Section I, the said employee or agent may use a reasonable amount of nondeadly force when and only when such force is necessary to protect the employee or agent or to prevent the escape of the person being detained or the loss of the library's property.

(CLS cont. from page 272)

ACRL. "Statement on the Terminal Professional Degree for Academic Librarians." Chicago: ALA/ACRL, 1975.

ALA, Ad Hoc Committee on the Physical Facilities of Libraries. Measurement and Comparison of Pbysical Facilities for Libraries. Chicago: ALA, 1970.

ALA. "Library Bill of Rights" (ALA Policy Manual, Section 53.1). In ALA Handbook of Organization 1993/1994. Chicago: AlA, 1993, p. H147.

ALA. "Library Education and Personnel Utilization: A Statement of Policy. "Adopted by ALA Council. Chicago: ALA/OLPR, 1970.

ALA, RSDA/FLA. National Interlibrary Loan Code, 1980; International Lending Principles and Guidelines, 1978. Chicago: ALA, 1982.

Carpenter, Ray L. "College Libraries: A Comparative Analysis in Terms of the ACRL Standards." College \& Research Libraries 42 (January 1981): $7-18 . B$

Coleman, Paul, and Ada Jarred. "Regional Accreditation Criteria and the Standards for College Libraries: A Comparative Study." Paper submitted for publication, 1994

Kaser, David. "Standards for College Librar-
Section III. An adult agent or employee of a library who stops, detains, and/or causes the arrest of any person pursuant to Section II shall not be held civilly liable for false arrest, false imprisonment, unlawful detention, assault, battery, defamation of character, malicious prosecution, or invasion of civil rights of the person stopped, detained, and/or arrested, provided that in stopping, detaining, or causing the arrest of the person, the adult agent or employee had at the time of the stopping, detention, or arrest reasonable grounds to believe that the person had committed, was committing, or was attempting to commit any of the crimes set forth in Section I.

Section $I V$. The fair market value of property affected by crimes set forth in Section I determines the class of offense: value under $\$ 500$ indicates a misdemeanor; $\$ 500-\$ 5,000$ a Class I felony; above $\$ 5,000$, a Class II felony.

The aggregate value of all property referred to in a single indictment shall constitute the value thereof

Section $V$. A copy or abstract of this act shall be posted and prominently displayed in all libraries.

Section Vi. This act shall take effect upon passage.

ies." Library Trends 31:1 (Summer 1982): 7-19.

Hardesty, Larry, and Stella Bentley. The Use and Effectiveness of the 1975 Standards for College Libraries: A Survey of College Library Directors (1981).. Unpublished paper.

Leach, Ronald G., and Judith E. Tribble. "Electronic Document Delivery: New Options for Libraries." Joumal of Academic Librariansbip 18 (January 1993): 359-64.

Matier, Michael, and C. Clinton Sidle. "What Size Libraries for 2010?" Planning for Higber Education 21 (Summer 1993): 9-15

Morgan, Robert L. Classification of Instructional Programs. 1990 edition. Washington, D.C.: National Center for Education Statistics, 1991

Stueart, Robert D., and Barbara B. Moran. "Missions, Goals and Objectives." In Library and Information Center Management, 4th ed. Englewood, Colo.: Libraries Unlimited, 1993, pp. 43-45.

U.S. Code. 1-810. "Act for the General Revision of the Copyright Law." October 9, 1976. Public Law 94-553,90 Stat. 2541

Walch, David B. "The 1986 College Library Standards: Application and Utilization." College E Research Libraries 54 (May 1993): 217-26. 